\title{
Obesity Does Not Increase the Risk of Asthma Readmissions
}

\author{
Francisco-Javier Gonzalez-Barcala ${ }^{1,2,3,4} \mathbb{D}$, Juan-José Nieto-Fontarigo $5,6, * \mathbb{C}$, \\ Tamara Lourido-Cebreiro ${ }^{3}$, Carlota Rodríguez-García ${ }^{3}$, Maria-Esther San-Jose ${ }^{7}$, \\ Jose-Martín Carreira ${ }^{8}$, Uxio Calvo-Alvarez ${ }^{9}$, Maria-Jesus Cruz ${ }^{2,10}$, David Facal ${ }^{11}{ }^{10}$, \\ Maria-Teresa Garcia-Sanz ${ }^{12}{ }^{1}$, Luis Valdes-Cuadrado ${ }^{1,3,4}$ and Francisco-Javier Salgado ${ }^{5}$
}

1 Department of Medicine, Universidade de Santiago de Compostela, 15705 Santiago de Compostela, Spain; Francisco.javier.gonzalez.barcala@sergas.es (F.-J.G.-B.); Luis.Valdes.Cuadrado@sergas.es (L.V.-C.)

2 Spanish Biomedical Research Networking Centre-CIBERES, 28029 Madrid, Spain; mj.cruz@vhir.org

3 Department of Respiratory Medicine, University Hospital of Santiago de Compostela (CHUS), 15706 Santiago de Compostela, Spain; Tamara.lourido.cebreiro@sergas.es (T.L.-C.); crodgar5@gmail.com (C.R.-G.)

4 Health Research Institute of Santiago de Compostela (IDIS), 15706 Santiago de Compostela, Spain

5 Department of Biochemistry and Molecular Biology, Faculty of Biology-Biological Research Centre (CIBUS), Universidade de Santiago de Compostela, 15706 Santiago de Compostela, Spain; franciscojavier.salgado@usc.es

6 Department of Experimental Medical Science, Respiratory Immunopharmacology group, Lund University, 22362 Lund, Sweden

7 Clinical Analysis Service, University Hospital of Santiago de Compostela (CHUS), 15706 Santiago de Compostela, Spain; sanjosec@yahoo.com

8 Department of Radiology, Universidade de Santiago de Compostela, 15706 Santiago de Compostela, Spain; josemartin.carreira@usc.es

9 Department of Respiratory Medicine, University Hospital of Ferrol, 15045 Ferrol, Spain; uxve@msn.com

10 Department of Respiratory Medicine, Hospital Vall d'Hebron, 08023 Barcelona, Spain

11 Department of Developmental Psychology, Universidade de Santiago de Compostela, 15706 Santiago de Compostela, Spain; david.facal@usc.es

12 Emergency Department, Hospital O Salnes, 36600 Vilagarcía de Arousa, Spain; maytegsanz@gmail.com

* Correspondence: juanjose.nieto.fontarigo@gmail.com; Tel.: +34-699234098

Received: 1 December 2019; Accepted: 12 January 2020; Published: 14 January 2020

\begin{abstract}
The relationship between obesity and asthma exacerbations is still under debate. The aim of our work is to analyse the relationship between obesity and hospital re-admissions in asthmatics. A review was retrospectively performed on all hospital admissions of adult patients due to asthma exacerbation occurring in our hospital for 11 years. All those cases with asthma as the first diagnosis in the discharge report were included, or those with asthma as the second diagnosis provided when the first diagnosis was respiratory infection or respiratory failure. Only the first hospital admission of each patient was included in this study. The Odds Ratios of a higher incidence of early/late readmissions due to asthma exacerbation were calculated using a binary logistic regression, using the body mass index (BMI) as independent variable, adjusted for all the variables included in the study. The study included 809 patients with a mean age of 55.6 years, and $65.2 \%$ were female. The majority $(71.4 \%)$ were obese or overweight. No significant relationship was observed in the univariate or multivariate analyses between overweight or obesity and the early or late hospital readmissions due to asthma. Therefore, obesity does not seem to be a determining factor in the risk of asthma exacerbations.
\end{abstract}

Keywords: asthma exacerbations; obesity; hospital readmissions; prognosis 


\section{Introduction}

Obesity is a significant health problem that affects more than 500 million people in the world, and more than 1.5 billion people are overweight [1]. Asthma is also an illness with an elevated prevalence. In 2016, the Global Burden of Disease (GBD) study estimated that there were 339.4 million people worldwide affected by asthma. This represents a $3.6 \%$ increase in age-standardised prevalence since 2006 [2]. This increase in the prevalence of asthma in such a short time is probably more related to environmental than genetic factors [3,4]. It also has a large impact on the population as asthma is ranked 16th overall among the leading causes of years lived with disability, and 28th among the leading causes of burden of disease [2]. Mortality appears to be reducing, although with the significant differences between countries and age groups, it continues to be elevated. In 2016, the GBD collaboration estimated that 420,000 people in the world died from asthma (i.e., more than 1000 per day) [2,5].

Obesity is one of the factors that is being investigated as a possible cause of asthma or of a worse prognosis of the disease. Two asthma phenotypes associated with obesity have been identified. One with early-onset asthma, usually triggered by allergens, with eosinophilia and an elevated IgE, and aggravated by obesity. The other phenotype is usually of late onset, mainly in women, with low Th2 markers with an increase in leptin and interleukin 6 [6].

However, the relationship between obesity and asthma is not clear, with significant divergences between different authors in most of the features analysed. On analysing the prevalence of asthma, some authors showed that obesity was associated with significant increases in its prevalence [7-9], whilst others mentioned that obesity did not affect asthma [10,11], and in other cases that it may be associated with prevalence in some age groups, but not in others [12]. Regarding the control of the disease, it is still under debate, with some authors observing a poorer control in the obese population [13-15], whilst in other publications, the increase in weight does not appear to have an influence on the control of asthma $[8,16,17]$. On analysing the impact of obesity on the incidence of exacerbations, there are still discrepancies between authors. Some do not observe a relationship between the increase in weight and the incidence of exacerbations in some cases $[17,18]$, but in other publications it is mentioned that exacerbations are more common with an increase in weight $[15,19,20]$. However, obesity does not appear to be associated with the severity of the exacerbations or in the time required to recover from them [21-23]. Regarding the quality of life, the negative effect of obesity appears to be clearer in this respect, with a worsening of quality of life with an increase in weight $[13,15,24]$.

Due to these discrepancies, the aim of our study was to analyse the possible relationship of obesity with hospital readmissions in patients with asthma.

\section{Material and Methods}

A review was retrospectively carried out on all hospital admissions of patients over 18 years old due to exacerbation of asthma occurring in our hospital between the years 2000 and 2010.

The data were gathered by two members of the research team by reviewing the clinical records. In cases where there were discrepancies in the evaluation of any data, the decision was made by consensus with the rest of the group members. Follow-up treatment of these patients was carried out after discharge by specialists in Respiratory Medicine or Internal Medicine.

All those cases with asthma as the first diagnosis in the discharge report were included, or those with asthma as the second diagnosis provided that the first diagnosis was respiratory infection or respiratory failure. Cases were excluded if the admission was due to another specific cause, such as pulmonary embolism or pneumonia. The patients were diagnosed and treated according to the decision of the treating physician. Only the first hospital admission of each patient was included in this study.

The personal characteristics of each patient were obtained from the clinical records in stable state, including age, gender, body mass index (BMI), classifying the patients into normal weight when they had a BMI less than $25 \mathrm{~kg} / \mathrm{m}^{2}$, as overweight with a BMI greater than or equal to 25 , and a BMI greater than or equal to 30 as obese [25]. Comorbidity was evaluated according to the Charlson index [26], and smoking classified as active smokers, ex-smokers, or never smoked. 
An analysis was performed on the asthma personal history, lung function based on the forced expiratory volume (FEV1) as a percentage of the reference value, the baseline severity of the asthma according to the Global Initiative for Asthma (GINA) 2006 criteria [27], having presented with any episode of near-fatal asthma (NFA) [22], and hospital emergency department (ED) visits or admissions due to asthma in the previous year and treatment after hospital discharge.

Previous year emergencies were stratified into three groups: one group of those who did not make any visit to the ED in the previous year, another that made one to three visits, and a last group that made four or more visits to the ED in the previous year. Previous year hospital admissions were stratified into three groups: one group of those who did not have any hospital admission in the previous year, another that had one hospital admission, and a last group that had two or more hospital admissions in the previous year.

Early readmission (ER) was defined as that which occurred in the following 15 days after hospital discharge, and late readmission (LR) occurred from 16 days after discharge [28].

These patients were followed-up during the inclusion period from 2000 to 2010 . The follow-up period was extended for one year for patients including during 2010, hence every patient was monitored for at least one year.

The Review Board on Human Studies at our institution approved the protocol (Register Code: 2017/093).

\section{Statistical Analysis}

The data were tested for normal distribution using the Kolmogorov-Smirnov test. The comparison of the categorical variables was performed using the Chi-squared test. For the comparison of the continuous variables, the $t$-student test was used.

The Odds Ratios (OR) of a higher incidence of ER and LR were calculated using a binary logistic regression, using body mass index as independent variable, adjusted for all the variables included in the study: age, gender, Charlson index, smoking habit, asthma severity, hospital admissions and emergency visits in the previous year due to asthma, and treatment after hospital discharge with combinations of inhaled corticosteroids and long acting beta-agonists (ICS-LABA), inhaled, or oral corticosteroids.

All statistical analyses were performed using SPSS for Windows, Version 15.0 (SPSS Inc., Chicago, IL, USA).

\section{Results}

The study included 809 patients with a mean age of 55.6 years, and $65.2 \%$ were female. The majority $(71.4 \%)$ were obese or overweight (Table 1$)$. As expected, the obese patients were more likely to be female, older, with more comorbidity, less frequent smokers, higher asthma severity, and with more frequent emergency visits (Table 1$)$. There were early readmissions by 18 patients $(2.2 \%)$, late readmissions in 168 patients $(20.8 \%)$, and $54(7.8 \%)$ patients with two or more late readmissions.

Table 1. Main characteristics of the included patients.

\begin{tabular}{cccccc}
\hline Variable & Total & Normal Weight & Overweight & Obesity & $p$ \\
\hline Age, mean (SD) & $55.6(19.5)$ & $44.6(20.7)$ & $58.5(19.2)$ & $61.5(14.9)$ & $\mathbf{0 . 0 0 0}$ \\
\hline Gender, $n(\%)$ & & & & & \\
Male & $281(34.8)$ & $87(37.8)$ & $122(42.4)$ & $72(24.9)$ & $\mathbf{0 . 0 0 0}$ \\
Female & $526(65.2)$ & $143(62.2)$ & $166(57.6)$ & $217(75.1)$ & \\
\hline FEV1\% & & & & \\
$\geq 80 \%$ & $307(38.1)$ & $98(42.4)$ & $105(36.7)$ & $104(36.0)$ & 0.556 \\
$\geq 60-80 \%$ & $221(27.4)$ & $62(26.8)$ & $78(27.3)$ & $81(28.0)$ & \\
$<60 \%$ & $278(34.5)$ & $71(30.7)$ & $103(36.0)$ & $104(36.0)$ & \\
\hline
\end{tabular}


Table 1. Cont.

\begin{tabular}{|c|c|c|c|c|c|}
\hline Variable & Total & Normal Weight & Overweight & Obesity & $p$ \\
\hline \multicolumn{6}{|l|}{ Charlson index } \\
\hline 0 & $337(41.7)$ & $126(54.5)$ & $108(37.5)$ & $103(35.5)$ & \multirow{3}{*}{0.000} \\
\hline 1 & $266(32.9)$ & $78(33.8)$ & $98(34.0)$ & $90(31.0)$ & \\
\hline$\geq 2$ & $206(25.5)$ & 27 (11.7) & $82(28.5)$ & $97(33.5)$ & \\
\hline \multicolumn{6}{|l|}{ Smokers } \\
\hline Never smoker, $n(\%)$ & $380(59.7)$ & $89(46.4)$ & $139(62.3)$ & $152(68.8)$ & \multirow{3}{*}{0.000} \\
\hline Current smoker, $n(\%)$ & $166(26.1)$ & $80(41.7)$ & $46(20.6)$ & $40(18.1)$ & \\
\hline Former smoker, $n(\%)$ & $90(14.2)$ & $23(12.0)$ & $38(17.0)$ & $29(13.1)$ & \\
\hline \multicolumn{6}{|l|}{ Asthma severity } \\
\hline Intermittent, $n(\%)$ & $177(26.2)$ & $71(34.6)$ & $64(27.1)$ & $42(17.9)$ & \multirow{4}{*}{0.000} \\
\hline Mild, $n(\%)$ & $168(24.9)$ & $53(25.9)$ & $52(22.0)$ & $63(26.9)$ & \\
\hline Moderate, $n(\%)$ & $162(24.0)$ & $48(23.4)$ & $60(25.4)$ & $54(23.1)$ & \\
\hline Severe, $n(\%)$ & $168(24.9)$ & $33(16.1)$ & $60(25.4)$ & $75(32.1)$ & \\
\hline \multicolumn{6}{|c|}{ Hospital admissions previous yea } \\
\hline $0, \mathrm{~N}(\%)$ & $671(82.9)$ & $204(88.3)$ & $231(80.2)$ & $236(81.4)$ & \multirow{3}{*}{0.093} \\
\hline $1, \mathrm{~N}(\%)$ & $103(12.7)$ & $20(8.7)$ & $45(15.6)$ & $38(13.1)$ & \\
\hline$\geq 2, \mathrm{~N}(\%)$ & $35(4.3)$ & $7(3.0)$ & $12(4.2)$ & $16(5.5)$ & \\
\hline \multicolumn{6}{|c|}{ Emergency visits previous year } \\
\hline $0, \mathrm{~N}(\%)$ & $589(72.9)$ & $188(81.4)$ & $198(68.8)$ & $203(70.2)$ & \multirow[t]{3}{*}{0.009} \\
\hline $1-3, N(\%)$ & $198(24.5)$ & $38(16.5)$ & $84(29.2)$ & $76(26.3)$ & \\
\hline$\geq 4, \mathrm{~N}(\%)$ & $21(2.6)$ & $5(2.2)$ & $6(2.1)$ & $10(3.5)$ & \\
\hline \multicolumn{6}{|c|}{ ICS-LABA at hospital discharge } \\
\hline No & $244(30.2)$ & $75(32.5)$ & $89(30.9)$ & $80(27.6)$ & \multirow[t]{2}{*}{0.456} \\
\hline Yes & $565(69.8)$ & $156(67.5)$ & $199(69.1)$ & $210(72.4)$ & \\
\hline \multicolumn{6}{|l|}{ ICS at hospital discharge } \\
\hline No & $652(80.6)$ & $184(79.7)$ & $225(78.1)$ & $243(83.8)$ & \multirow[t]{2}{*}{0.207} \\
\hline Yes & $157(19.4)$ & $47(20.3)$ & $63(21.9)$ & $47(16.2)$ & \\
\hline \multicolumn{6}{|l|}{ OCS at hospital discharge } \\
\hline No & $245(30.3)$ & $71(30.7)$ & $99(34.4)$ & $75(25.9)$ & \multirow[t]{2}{*}{0.082} \\
\hline Yes & $564(69.7)$ & $160(69.3)$ & $189(65.6)$ & $215(74.1)$ & \\
\hline
\end{tabular}

SD: standard deviation; n: number of cases; FEV1\%: Forced expiratory volume in the first second, percentage of reference value; ICS-LABA: combination inhaled corticosteroids-long acting beta agonists; ICS: inhaled corticosteroids; OCS: oral corticosteroids.

No significant relationship was observed in the univariate or multivariate analyses between overweight or obesity and the early or late hospital readmissions due to asthma (Tables 2 and 3). Neither was there a correlation between obesity and FEV1 (Table 1).

Table 2. Number of patients with early and late readmissions according to Body Mass Index using Univariate analysis.

\begin{tabular}{|c|c|c|c|c|c|c|c|c|c|c|c|c|}
\hline & \multicolumn{2}{|c|}{$\begin{array}{c}\text { Early Readmission } \\
n(\%)\end{array}$} & \multirow{2}{*}{$\begin{array}{c}p \\
0.37\end{array}$} & \multicolumn{2}{|c|}{$\begin{array}{l}\text { Late Readmission } \\
n(\%)\end{array}$} & \multirow{2}{*}{$\begin{array}{c}p \\
0.44\end{array}$} & \multicolumn{2}{|c|}{$\begin{array}{c}\text { Frequent Late } \\
\text { Readmission, } n(\%)\end{array}$} & \multirow{2}{*}{$\begin{array}{c}p \\
0.12\end{array}$} & \multicolumn{2}{|c|}{$\begin{array}{c}\text { Any Readmission, } \\
n(\%)\end{array}$} & \multirow{2}{*}{$\begin{array}{c}p \\
0.29\end{array}$} \\
\hline & 0 & $\geq 1$ & & 0 & $\geq 1$ & & 0 & $\geq 2$ & & 0 & $\geq 1$ & \\
\hline $\begin{array}{c}\text { Normal weight, } \\
n(\%)\end{array}$ & $226(97.8)$ & $5(2.2)$ & & $189(81.8)$ & $42(18.2)$ & & $189(95.5)$ & $9(4.5)$ & & $186(80.5)$ & 45 (19.5) & \\
\hline $\begin{array}{c}\text { Overweight, } \\
n(\%)\end{array}$ & $284(98.6)$ & $4(1.4)$ & & $228(79.2)$ & $60(20.8)$ & & $228(90.5)$ & $24(9.5)$ & & 225 (78.1) & $63(21.9)$ & \\
\hline $\begin{array}{c}\text { Obesity, } \\
n(\%)\end{array}$ & $281(96.9)$ & $9(3.1)$ & & $224(77.2)$ & $66(22.8)$ & & $224(91.4)$ & $21(8.6)$ & & 217 (74.8) & $73(25.2)$ & \\
\hline
\end{tabular}

Early readmission: in the following 15 days after hospital discharge ( 0 versus $\geq 1$ readmissions); Late readmission: from 16 days after discharge ( 0 versus $\geq 1$ readmissions); Frequent late readmission: from 16 days after discharge $(0$ versus $\geq 2$ readmissions); $n$ : number of cases. 
Table 3. Multivariate analysis of readmissions according to Body Mass Index.

\begin{tabular}{|c|c|}
\hline & OR (CI 95\%) \\
\hline \multicolumn{2}{|c|}{ EARLY READMISSION ( 0 versus $\geq 1$ ) } \\
\hline Normal weight & 1 \\
\hline Overweight & $0.410(0.101-1.668)$ \\
\hline Obesity & $0.840(0.244-2.890)$ \\
\hline \multicolumn{2}{|c|}{ LATE READMISSION (0 versus $\geq 1$ ) } \\
\hline Normal weight & 1 \\
\hline Overweight & $0.734(0.448-1.203)$ \\
\hline Obesity & $0.778(0.473-1.280)$ \\
\hline \multicolumn{2}{|c|}{ FREQUENT LATE READMISSION (0 versus $\geq 2$ ) } \\
\hline Normal weight & 1 \\
\hline Overweight & $1.351(0.570-3.204)$ \\
\hline Obesity & $1.146(0.464-2.831)$ \\
\hline \multicolumn{2}{|c|}{ ANY READMISSION ( 0 versus $\geq 1$ ) } \\
\hline Normal weight & 1 \\
\hline Overweight & $0.858(0.461-1.597)$ \\
\hline Obesity & $0.841(0.450-1.571)$ \\
\hline
\end{tabular}

OR: Odds Ratio; CI: Confidence interval; ICS-LABA: combination inhaled corticosteroids-long acting beta agonists; ICS: inhaled corticosteroids; OCS: oral corticosteroids; Adjusted by age, gender, FEV1\% (Forced expiratory volume in the first second), percentage of reference value, Charlson index (comorbidity), smoking habit, asthma severity, frequency of hospital admissions and emergency visits in the previous year, and treatment at hospital discharge (ICS-LABA, ICS, OCS).

\section{Discussion}

The relationship between obesity and asthma has been widely studied, but the relationship between processes continues to be debated due to the lack of agreement between the different studies.

In our population of asthmatics who required any hospital readmission, more than $71 \%$ were obese or overweight, but this is not associated with the incidence of hospital readmissions. Our results are in agreement with the other authors who did not observe a relationship between obesity and exacerbations or with the control of the asthma [8,16,21,29-31], although it was different from other studies where we showed a poorer control of asthma or increase in the incidence of the exacerbations with obesity [13-15,19,20,32-36].

The disagreement between the results of the various studies, as well as the demonstration that some mechanisms that appear to support a relationship between obesity and asthma, seem to indicate that there probably could be various phenotypes within the asthma-obesity syndrome. In fact, the response to weight loss is very different in patients with early-onset atopic asthma, where the disease does not remit even in the case of weight loss, although it can improve the symptoms. The disease was resolved when they lost weight for those included in the late-onset non-atopic asthma phenotype [37].

Some authors suggest that the discordant results could be due to methodological issues [34]. On the one hand, the BMI may not be a good indicator of body fat since it does not differentiate fat-mass from fat-free mass, being able to be a muscle mass indicator, especially in young males [1]. Furthermore, it is known that the asthma diagnosis in obese patients is more difficult due to over-diagnosis as well as underdiagnosis, as such that it could interfere in drawing precise conclusions from the studies [38].

Other studies include patients with an asthma diagnosis based on questionnaires completed by the patients themselves. In these cases, there could be incorrect interpretations of the symptoms, interpreting as asthma that which is due to the obesity [21].

It is known that some factors that produce obesity can also lead to a poor progression of the asthma. Thus, animal models demonstrate that a diet rich in fructose leads to systemic metabolic dysfunction, increase in bronchial hyperresponsiveness (BHR), and oxidative stress in the airway [39]. Furthermore, it has been observed in children that a higher consumption of sugary drinks is associated 
with a higher risk of asthma [40]. Adherence to a Mediterranean diet has also been associated with less obesity and a lower risk of asthma [41-43]. These findings suggest that, at least in part, the relationship between obesity and asthma could not be a direct relationship between both, but that it could be determined by other underlying factors.

Another thing to consider is that some comorbidities are not evaluated in the different studies, which could affect the results obtained. In this sense, it has recently been suggested that there is a possible relationship of asthma with ischaemic heart disease regardless of the presence of other vascular risk factors [44]. Another comorbidity that has been associated with asthma is obstructive sleep apnoea and is not analysed in most studies [45]. Gastroesophageal reflux disease is common in obese patients, and it well known that it is a risk factor for exacerbations of asthma [46].

The possibility of a reverse causation has also been proposed, as such that asthma may be the cause of the obesity, as suggested in other studies, which would complicate the interpretation of the true relationship between obesity and asthma $[47,48]$. On the other hand, the various pieces of pathophysiological evidence coming from animal models as well as studies in humans seem to support the detrimental effect of the obesity on the asthma prognosis.

The inflammation of the airway is different between obese and non-obese asthmatics. In a mouse model it was observed that in obese mice, after an ovalbumin challenge, the inflammation in the airway was more intense [49]. Van der Wiel et al. mentioned that in obese patients with mild-moderate asthma there was no correlation between eosinophilia in sputum and that obtained in the submucosa of the airway, presenting with elevated eosinophilia in the submucosa even in the absence of eosinophilia in the sputum. However, in the non-obese there is a correlation between the tissue eosinophilia and the increase of eosinophils in sputum [50].

Hormonal factors could also play a role. The leptin levels increase in obese individuals, and those of adiponectin are reduced [51]. The increase in leptin is higher in obese patients with asthma than in obese ones without asthma [52]. It is known that leptin is a pro-inflammatory adipokine that correlates negatively with lung function and with the increase in reactivity to methacholine, whilst adiponectin has anti-inflammatory properties [52-54]. A greater hyperresponsiveness has been observed in cultured human airway smooth muscle cells from obese asthmatics [55].

Another aspect that has been associated with a poor asthma prognosis in obese patients is a lower response to the usual asthma treatments, especially to the corticoids $[1,55]$.

The obesity itself causes a deterioration in lung function, with the functional residual capacity (FRC) and residual volume being particularly affected, as well as leading to a reduction in the FEV1 [56-59]. The reduction in FRC favours the increase in the BHR, one of the main characteristics of asthma [37]. Even in non-obese individuals, it is known that a greater fat-mass has a negative impact on lung function [60]. Another argument in favour of the relationship between obesity and a poor asthma prognosis is the favourable response to the weight loss, whether by diet and exercise or with bariatric surgery, with improvements in the asthma symptoms and lung function [61-64].

During the year before the index hospital admission, obese patients had more exacerbations without any difference in hospital admissions. Similarly, they don't have more frequent readmissions during the follow-up period. In the literature, asthma exacerbations requiring hospital admission are usually a minority, since most patients are discharged from the Emergency Room [14,65].

Finally, our study includes some limitations. On including patients with hospital admissions, they might not be representative of the general asthmatic population. It could be that obese patients are over-represented due to having a higher probability of admissions due to other comorbidities $[45,46]$. Given that it is a retrospective study, all the variables of all the patients were not available. Furthermore, we didn't analyse the effect of some relevant characteristics, such as allergic sensitization, because they were available in a few patients. Likewise, all the patients were from a single university hospital, which may affect the external validity of the study. On the other hand, one strength of this study is that the reliability of the asthma diagnosis, when it comes from hospital discharge reports, is elevated [66]. 
In conclusion, obesity does not seem to be a determining factor in the risk of asthma exacerbations. It may have a higher impact in some phenotypes, and other underlying factors, such as the comorbidities common to both diseases, may play a role in this complex interaction.

Author Contributions: Conceptualization, F.-J.G.-B., J.-J.N.-F., M.-J.C. and F.-J.S.; Data curation, F.-J.G.-B., J.-J.N.-F., T.L.-C., C.R.-G., M.-E.S.-J., J.-M.C., U.C.-A., M.-J.C., D.F., M.-T.G.-S., L.V.-C. and F.-J.S.; Formal analysis, F.-J.G.-B., J.-J.N.-F., T.L.-C., C.R.-G., M.-E.S.-J., J.-M.C., U.C.-A., M.-J.C., D.F., M.-T.G.-S., L.V.-C. and F.-J.S.; Investigation, F.-J.G.-B.; Project administration, F.-J.G.-B.; Supervision, F.-J.G.-B. and F.-J.S.; Writing-original draft, F.-J.G.-B., C.R.-G., M.-E.S.-J., J.-M.C., U.C.-A. and M.-J.C.; Writing-review \& editing, F.-J.G.-B., J.-J.N.-F., T.L.-C., C.R.-G., M.-E.S.-J., J.-M.C., U.C.-A., M.-J.C., D.F., M.-T.G.-S., L.V.-C. and F.-J.S. All authors have read and agreed to the published version of the manuscript.

Conflicts of Interest: F.-J.G.-B. has received speaker fees, consulting fees or research grants from Chiesi, Menarini, Rovi, Bial, GlaxoSmithKline, Laboratorios Esteve, Teva, Gebro Pharma, ALK, Roxall, Stallergenes-Gree, Boehringer Ingelheim, Mundipharma and Novartis.

\section{References}

1. Carpaij, O.A.; van den Berge, M. The asthma-obesity relationship: Underlying mechanisms and treatment implications. Curr. Opin. Pulm. Med. 2018, 24, 42-49. [CrossRef]

2. The Global Asthma Report 2018. Available online: www.http://www.globalasthmareport.org (accessed on 6 October 2019).

3. Cruz, M.J.; Romero-Mesones, C.; Muñoz, X. Can Environmental Pollution Cause Asthma? Arch. Bronconeumol 2018, 54, 121-122. [CrossRef] [PubMed]

4. Muñoz, X.; Barreiro, E.; Bustamante, V.; Lopez-Campos, J.L.; González-Barcala, F.J.; Cruz, M.J. Diesel exhausts particles: Their role in increasing the incidence of asthma. Reviewing the evidence of a causal link. Sci. Total Environ. 2019, 652, 1129-1138. [CrossRef] [PubMed]

5. Gonzalez-Barcala, F.J.; Aboal, J.; Carreira, J.M.; Rodriguez-Alvarez, M.X.; Puga, A.; Sanjose, E.; Pintos, M.; Valdes, L. Trends of asthma mortality in Galicia from 1993 to 2007. J. Asthma 2012, 49, 1016-1020. [CrossRef] [PubMed]

6. Carr, T.F.; Kraft, M. Use of biomarkers to identify phenotypes and endotypes of severe asthma. Ann. Allergy Asthma Immunol. 2018, 121, 414-420. [CrossRef]

7. Khalid, F.; Holguin, F. A review of obesity and asthma across the life span. J. Asthma 2018, 55, 1286-1300. [CrossRef]

8. Kourlaba, G.; Bakakos, P.; Loukides, S.; Vellopoulou, K.; Solakidi, A.; Maniadakis, N. The self-reported prevalence and disease burden of asthma in Greece. J. Asthma 2019, 56, 478-497. [CrossRef]

9. Myung, J.; Lee, H.; Kim, T.H.; Han, E. Relationships between self-reported asthma and pulmonary function and various measures of obesity. J. Asthma 2018, 55, 741-749. [CrossRef]

10. Arias, S.J.; Neffen, H.; Bossio, J.C.; Calabrese, C.A.; Videla, A.J.; Armando, G.A.; Antó, J.M. Prevalence and Features of Asthma in Young Adults in Urban Areas of Argentina. Arch. Bronconeumol. 2018, 54, 134-139. [CrossRef]

11. den Dekker, H.T.; Ros, K.P.I.; de Jongste, J.C.; Reiss, I.K.; Jaddoe, V.W.; Duijts, L. Body fat mass distribution and interrupter resistance, fractional exhaled nitric oxide, and asthma at school-age. J. Allergy Clin. Immunol. 2017, 139, 810-818. [CrossRef]

12. Gonzalez-Barcala, F.J.; Pertega, S.; Perez-Castro, T.; Sampedro, M.; Sanchez-Lastres, J.; San-Jose-Gonzalez, M.A.; Bamonde, L.; Garnelo, L.; Valdés-Cuadrado, L.; Moure, J.D.; et al. Obesity and asthma: An association modified by age. Allergol. Immunopathol. (Madr) 2013, 41, 176-180. [CrossRef]

13. Denlinger, L.C.; Phillips, B.R.; Ramratnam, S.; Ross, K.; Bhakta, N.R.; Cardet, J.C.; Castro, M.; Peters, S.P.; Phipatanakul, W.; Aujla, S.; et al. Inflammatory and Comorbid Features of Patients with Severe Asthma and Frequent Exacerbations. Am. J. Respir. Crit. Care. Med. 2017, 195, 302-313. [CrossRef] [PubMed]

14. Neffen, H.; Chahuàn, M.; Hernández, D.D.; Vallejo-Perez, E.; Bolivar, F.; Sánchez, M.H.; Galleguillos, F.; Castaños, C.; Silva, R.; Giugno, E.; et al. Key factors associated with uncontrolled asthma-the Asthma Control in Latin America Study. J. Asthma. 2019, 1-10. [CrossRef] [PubMed]

15. Tay, T.R.; Radhakrishna, N.; Hore-Lacy, F.; Smith, C.; Hoy, R.; Dabscheck, E.; Hew, M. Comorbidities in difficult asthma are independent risk factors for frequent exacerbations, poor control and diminished quality of life. Respirology 2016, 21, 1384-1390. [CrossRef] 
16. González-Barcala, F.J.; de la Fuente-Cid, R.; Alvarez-Gil, R.; Tafalla, M.; Nuevo, J.; Caamaño-Isorna, F. Factors associated with asthma control in primary care patients: The CHAS study. Arch. Bronconeumol. 2010, 46, 358-363.

17. Clerisme-Beaty, E.M.; Karam, S.; Rand, C.; Patino, C.M.; Bilderback, A.; Riekert, K.A.; Okelo, S.O.; Diette, G.B. Does higher body mass index contribute to worse asthma control in an urban population? J. Allergy Clin. Immunol. 2009, 124, 207-212. [CrossRef]

18. Gonzalez-Barcala, F.J.; Calvo-Alvarez, U.; Garcia-Sanz, M.T.; Garcia-Couceiro, N.; Martin-Lancharro, P.; Pose, A.; Carreira, J.M.; Moure-Gonzalez, J.D.; Valdes-Cuadrado, L.; Muñoz, X. Asthma exacerbations: Risk factors for hospital readmissions. Ir. J. Med. Sci. 2018, 187, 155-161. [CrossRef]

19. Tang, M.; Henderson, R.J.; Holbrook, J.T.; Que, L.G.; Mathews, A.M.; Wise, R.A.; Dixon, A.E.; Peters, S.P.; Rogers, L.; Smith, L.J.; et al. Does Obesity Increase Respiratory Tract Infections in Patients with Asthma? J. Allergy Clin. Immunol. Pract. 2019, 7, 954-961. [CrossRef]

20. Martin, A.; Bauer, V.; Datta, A.; Masi, C.; Mosnaim, G.; Solomonides, A.; Rao, G. Development and validation of an asthma exacerbation prediction model using electronic health record (EHR) data. J. Asthma 2019, 1-8. [CrossRef]

21. Yeh, K.H.; Skowronski, M.E.; Coreno, A.J.; Seitz, R.E.; Villalba, K.D.; Dickey-White, H.; McFadden, E.R. Impact of obesity on the severity and therapeutic responsiveness of acute episodes of asthma. J. Asthma 2011, 48, 546-552. [CrossRef]

22. Gonzalez-Barcala, F.J.; Calvo-Alvarez, U.; Garcia-Sanz, M.T.; Bourdin, A.; Pose-Reino, A.; Carreira, J.M.; Moure-Gonzalez, J.D.; Garcia-Couceiro, N.; Valdes-Cuadrado, L.; Muñoz, X. Characteristics and prognosis of near-fatal asthma exacerbations. Am. J. Med. Sci. 2015, 350, 98-102. [CrossRef] [PubMed]

23. Gonzalez-Barcala, F.J.; Calvo-Alvarez, U.; Salgado-Castro, F.J.; Facal, D.; Garcia-Sanz, M.T.; Muñoz, X.; Garcia-Couceiro, N.; Paz-Neira, O.; San-Jose, E.; Valdes-Cuadrado, L.; et al. Asthma exacerbations: Factors related to longer hospital stay. Acta. Clin. Belg. 2017, 72, 379-384. [CrossRef] [PubMed]

24. Gonzalez-Barcala, F.J.; de la Fuente-Cid, R.; Tafalla, M.; Nuevo, J.; Caamaño-Isorna, F. Factors associated with health-related quality of life in adults with asthma. A cross-sectional study. Multidiscip. Respir. Med. 2012, 7, 32. [CrossRef] [PubMed]

25. Obesity and Overweight. Available online: http://www.who.int/mediacentre/factsheets/fs311/en/ (accessed on 6 October 2019).

26. Charlson, M.E.; Pompei, P.; Ales, K.L.; MacKenzie, C.R. A new method of classifying prognostic comorbidity in longitudinal studies: Development and validation. J. Chronic Dis. 1987, 40, 373-383. [CrossRef]

27. The Global Asthma Report 2006. Available online: https://ginasthma.org/wp-content/uploads/2019/01/2006GINA.pdf (accessed on 6 October 2019).

28. Ashton, C.M.; Kuykendall, D.H.; Johnson, M.L.; Wray, N.P.; Wu, L. The association between the quality of inpatient care and early readmission. Ann. Intern. Med. 1995, 122, 415-421. [CrossRef]

29. Scott, L.; Li, M.; Thobani, S.; Nichols, B.; Morphew, T.; Kwong, K.Y. Factors affecting ability to achieve asthma control in adult patients with moderate to severe persistent asthma. J. Asthma 2016, 53, 644-649. [CrossRef]

30. Farah, C.S.; Kermode, J.A.; Downie, S.R.; Brown, N.J.; Hardaker, K.M.; Berend, N.; King, G.G.; Salome, C.M. Obesity is a determinant of asthma control independent of inflammation and lung mechanics. Chest 2011, 140, 659-666. [CrossRef]

31. Vandenplas, O.; Godet, J.; Hurdubaea, L.; Rifflart, C.; Suojalehto, H.; Walusiak-Skorupa, J.; Munoz, X.; Sastre, J.; Klusackova, P.; Moore, V.; et al. Severe Occupational Asthma: Insights from a Multicenter European Cohort. J. Allergy Clin. Immunol. Pract. 2019, 7, 2309-2318. [CrossRef]

32. Kasteleyn, M.J.; Bonten, T.N.; de Mutsert, R.; Thijs, W.; Hiemstra, P.S.; le Cessie, S.; Rosendaal, F.R.; Chavannes, N.H.; Taube, C. Pulmonary function, exhaled nitric oxide and symptoms in asthma patients with obesity: A cross-sectional study. Respir. Res. 2017, 18, 205. [CrossRef]

33. Rastogi, D.; Jung, M.; Strizich, G.; Shaw, P.A.; Davis, S.M.; Klein, O.L.; Penedo, F.J.; Ries, A.L.; Daviglus, M.L.; Moreiras, J.J.; et al. Association of systemic inflammation, adiposity, and metabolic dysregulation with asthma burden among Hispanic adults. Respir. Med. 2017, 125, 72-81. [CrossRef]

34. Hasegawa, K.; Tsugawa, Y.; Lopez, B.L.; Smithline, H.A.; Sullivan, A.F.; Camargo, C.A., Jr. Body mass index and risk of hospitalization among adults presenting with asthma exacerbation to the emergency department. Ann. Am. Thorac. Soc. 2014, 11, 1439-1444. [CrossRef] 
35. Schatz, M.; Zeiger, R.S.; Yang, S.J.; Chen, W.; Sajjan, S.; Allen-Ramey, F.; Camargo, C.A., Jr. Prospective Study on the Relationship of Obesity to Asthma Impairment and Risk. J. Allergy Clin. Immunol. Pract. 2015, 3, 560-565. [CrossRef] [PubMed]

36. Maio, S.; Baldacci, S.; Bresciani, M.; Simoni, M.; Latorre, M.; Murgia, N.; Spinozzi, F.; Braschi, M.; Antonicelli, L.; Brunetto, B.; et al. RItA: The Italian severe/uncontrolled asthma registry. Allergy 2018, 73, 683-695. [CrossRef] [PubMed]

37. Bates, J.H.T.; Poynter, M.E.; Frodella, C.M.; Peters, U.; Dixon, A.E.; Suratt, B.T. Pathophysiology to Phenotype in the Asthma of Obesity. Ann. Am. Thorac. Soc. 2017, 14 (Suppl. 5), S395-S398. [CrossRef] [PubMed]

38. van Huisstede, A.; Castro Cabezas, M.; van de Geijn, G.J. Underdiagnosis and overdiagnosis of asthma in the morbidly obese. Respir. Med. 2013, 107, 1356-1364. [CrossRef]

39. Singh, V.P.; Aggarwal, R.; Singh, S.; Banik, A.; Ahmad, T.; Patnaik, B.R.; Nappanveettil, G.; Singh, K.P.; Aggarwal, M.L.; Ghosh, B.; et al. Metabolic Syndrome Is Associated with Increased Oxo-Nitrative Stress and Asthma-Like Changes in Lungs. PLoS ONE 2015, 10, e0129850. [CrossRef] [PubMed]

40. Berentzen, N.E.; van Stokkom, V.L.; Gehring, U.; Koppelman, G.H.; Schaap, L.A.; Smit, H.A.; Wijga, A.H. Associations of sugar-containing beverages with asthma prevalence in 11-year-old children: The PIAMA birth cohort. Eur. J. Clin. Nutr. 2015, 69, 303. [CrossRef]

41. Konieczna, J.; Yañez, A.; Moñino, M.; Babio, N.; Toledo, E.; Martínez-González, M.A.; Sorlí, J.V.; Salas-Salvadó, J.; Estruch, R.; Ros, E.; et al. Longitudinal changes in Mediterranean diet and transition between different obesity phenotypes. Clin. Nutr. 2019, in press. [CrossRef]

42. Gonzalez Barcala, F.J.; Pertega, S.; Bamonde, L.; Garnelo, L.; Perez Castro, T.; Sampedro, M.; Sanchez Lastres, J.; San Jose Gonzalez, M.A.; Lopez Silvarrey, A. Mediterranean diet and asthma in Spanish schoolchildren. Pediatr. Allergy Immunol. 2010, 21, 1021-1027. [CrossRef]

43. Douros, K.; Thanopoulou, M.I.; Boutopoulou, B.; Papadopoulou, A.; Papadimitriou, A.; Fretzayas, A.; Priftis, K.N. Adherence to the Mediterranean diet and inflammatory markers in children with asthma. Allergol. Immunopathol. (Madr) 2019, 47, 209-213. [CrossRef]

44. Picado, C.; Pernigotti, A.; Arismendi, E. Asthma: A New Cardiovascular Risk Factor? Arch. Bronconeumol. 2019, 55, 353-354. [CrossRef]

45. Davies, S.E.; Bishopp, A.; Wharton, S.; Turner, A.M.; Mansur, A.H. The association between asthma and obstructive sleep apnea (OSA): A systematic review. J. Asthma 2019, 56, 118-129. [CrossRef] [PubMed]

46. Tashiro, H.; Shore, S.A. Obesity and severe asthma. Allergol. Int. 2019, 68, 135-142. [CrossRef] [PubMed]

47. Epstein, L.H.; Wu, Y.W.; Paluch, R.A.; Cerny, F.J.; Dorn, J.P. Asthma and maternal body mass index are related to pediatric body mass index and obesity: Results from the Third National Health and Nutrition Examination Survey. Obes. Res. 2000, 8, 575-581. [CrossRef] [PubMed]

48. Chen, Z.; Salam, M.T.; Alderete, T.L.; Habre, R.; Bastain, T.M.; Berhane, K.; Gilliland, F.D. Effects of Childhood Asthma on the Development of Obesity among School-aged Children. Am. J. Respir. Crit. Care Med. 2017, 195, 1181-1188. [CrossRef]

49. Silva, F.M.C.; Oliveira, E.E.; Gouveia, A.C.C.; Brugiolo, A.S.S.; Alves, C.C.; Correa, J.O.A.; Gameiro, J.; Mattes, J.; Teixeira, H.C.; Ferreira, A.P. Obesity promotes prolonged ovalbumin-induced airway inflammation modulating T helper type 1 (Th1), Th2 and Th17 immune responses in BALB/c mice. Clin. Exp. Immunol. 2017, 189, 47-59. [CrossRef]

50. van der Wiel, E.; Ten Hacken, N.H.; van den Berge, M.; Timens, W.; Reddel, H.K.; Postma, D.S. Eosinophilic inflammation in subjects with mild-to-moderate asthma with and without obesity: Disparity between sputum and biopsies. Am. J. Respir. Crit. Care Med. 2014, 189, 1281-1284. [CrossRef]

51. Arteaga-Solis, E.; Zee, T.; Emala, C.W.; Vinson, C.; Wess, J.; Karsenty, G. Inhibition of leptin regulation of parasympathetic signaling as a cause of extreme body weight-associated asthma. Cell Metab. 2013, 17, 35-48. [CrossRef]

52. Sideleva, O.; Suratt, B.T.; Black, K.E.; Tharp, W.G.; Pratley, R.E.; Forgione, P.; Dienz, O.; Irvin, C.G.; Dixon, A.E. Obesity and asthma: An inflammatory disease of adipose tissue not the airway. Am. J. Respir. Crit. Care Med. 2012, 186, 598-605. [CrossRef]

53. Huang, F.; Del-Río-Navarro, B.E.; Torres-Alcántara, S.; Pérez-Ontiveros, J.A.; Ruiz-Bedolla, E.; SaucedoRamírez, O.J.; Villafaña, S.; Sánchez Muñoz, F.; Bravo, G.; Hong, E. Adipokines, asymmetrical dimethylarginine, and pulmonary function in adolescents with asthma and obesity. J. Asthma 2017, 54, 153-161. [CrossRef] 
54. Orfanos, S.; Jude, J.; Deeney, B.T.; Cao, G.; Rastogi, D.; van Zee, M.; Pushkarsky, I.; Munoz, H.E.; Damoiseaux, R.; Di Carlo, D.; et al. Obesity increases airway smooth muscle responses to contractile agonists. Am. J. Physiol. Lung Cell Mol. Physiol. 2018, 315, L673-L681. [CrossRef] [PubMed]

55. Sutherland, E.R.; Goleva, E.; Strand, M.; Beuther, D.A.; Leung, D.Y. Body mass and glucocorticoid response in asthma. Am. J. Respir. Crit. Care Med. 2008, 178, 682-687. [CrossRef] [PubMed]

56. Sutherland, E.R.; Lehman, E.B.; Teodorescu, M.; Wechsler, M.E. National Heart, Lung, and Blood Institute's Asthma Clinical Research Network. Body mass index and phenotype in subjects with mild-to-moderate persistent asthma. J. Allergy Clin. Immunol. 2009, 123, 1328-1334. [CrossRef] [PubMed]

57. Sutherland, T.J.; Cowan, J.O.; Taylor, D.R. Dynamic hyperinflation with bronchoconstriction: Differences between obese and nonobese women with asthma. Am. J. Respir. Crit. Care Med. 2008, 177, 970-975. [CrossRef] [PubMed]

58. Deesomchok, A.; Fisher, T.; Webb, K.A.; Ora, J.; Lam, Y.M.; Lougheed, M.D.; O’Donnell, D.E. Effects of obesity on perceptual and mechanical responses to bronchoconstriction in asthma. Am. J. Respir. Crit. Care Med. 2010, 181, 125-133. [CrossRef] [PubMed]

59. Talaminos Barroso, A.; Márquez Martín, E.; Roa Romero, L.M.; Ortega Ruiz, F. Factors Affecting Lung Function: A Review of the Literature. Arch. Bronconeumol. 2018, 54, 327-332. [CrossRef]

60. Gonzalez-Barcala, F.J.; Takkouche, B.; Valdes, L.; Leis, R.; Alvarez-Calderon, P.; Cabanas, R.; Rodríguez Suarez, J.R.; Tojo, R. Body composition and respiratory function in healthy non-obese children. Pediatr. Int. 2007, 49, 553-557. [CrossRef]

61. Jensen, M.E.; Gibson, P.G.; Collins, C.E.; Hilton, J.M.; Wood, L.G. Diet-induced weight loss in obese children with asthma: A randomized controlled trial. Clin. Exp. Allergy 2013, 43, 775-784. [CrossRef]

62. Scott, H.A.; Gibson, P.G.; Garg, M.L.; Pretto, J.J.; Morgan, P.J.; Callister, R.; Wood, L.G. Dietary restriction and exercise improve airway inflammation and clinical outcomes in overweight and obese asthma: A randomized trial. Clin. Exp. Allergy 2013, 43, 36-49. [CrossRef]

63. Van Huisstede, A.; Rudolphus, A.; Castro Cabezas, M.; Biter, L.U.; van de Geijn, G.J.; Taube, C.; Hiemstra, P.S.; Braunstahl, G.J. Effect of bariatric surgery on asthma control, lung function and bronchial and systemic inflammation in morbidly obese subjects with asthma. Thorax 2015, 70, 659-667. [CrossRef]

64. Özbey, Ü.; Balaban, S.; Sözener, Z.Ç.; Uçar, A.; Mungan, D.; Mısırlıgil, Z. The effects of diet-induced weight loss on asthma control and quality of life in obese adults with asthma: A randomized controlled trial. J. Asthma 2019, 1-9. [CrossRef] [PubMed]

65. Naqvi, M.; Khachi, H. The barriers to accessing primary care resulting in hospital presentation for exacerbation of asthma or chronic obstructive pulmonary disease in a large teaching hospital in London. Respir. Med. 2016, 117, 162-165. [CrossRef] [PubMed]

66. Canadian Institute for Health Information. CIHI Data Quality Study of the 2005e2006 Discharge Abstract Database. Ottawa, Ontario. 2009. Available online: https://secure.cihi.ca/free_products/DAD_DQ_study_ 2005_2006_August_2009_e.pdf (accessed on 6 September 2019).

(C) 2020 by the authors. Licensee MDPI, Basel, Switzerland. This article is an open access article distributed under the terms and conditions of the Creative Commons Attribution (CC BY) license (http://creativecommons.org/licenses/by/4.0/). 